\title{
ALGORITMA DEEP LEARNING-LSTM UNTUK MEMPREDIKSI UMUR TRANSFORMATOR
}

\author{
Ayu Ahadi Ningrum ${ }^{*}$, Iwan Syarif ${ }^{2}$, Agus Indra Gunawan ${ }^{3}$, Edi Satriyanto ${ }^{4}$, Rosmaliati Muchtar ${ }^{5}$ \\ ${ }^{1,2,3,4}$ Departemen Teknik Informatika dan Komputer, Politeknik Elektronika Negeri Surabaya \\ ${ }^{5}$ Departemen Teknik Elektro, Institut Teknologi Sepuluh Nopember Surabaya \\ Email: : ${ }^{1}$ ayuahadinn@gmail.com, ${ }^{2}$ iwanarif@pens.ac.id, ${ }^{3}$ agus_ig@pens.ac.id, ${ }^{4}$ edi@pens.ac.id, \\ ${ }^{5}$ rosmaliati14@mhs.ee.its.ac.id \\ *Penulis Korespondensi
}

(Naskah masuk: 11 Januari 2021, diterima untuk diterbitkan: 09 Juni 2021)

\begin{abstract}
Abstrak
Kualitas dan ketersediaan pasokan listrik menjadi hal yang sangat penting. Kegagalan pada transformator menyebabkan pemadaman listrik yang dapat menurunkan kualitas layanan kepada pelanggan. Oleh karena itu, pengetahuan tentang umur transformator sangat penting untuk menghindari terjadinya kerusakan transformator secara mendadak yang dapat mengurangi kualitas layanan pada pelanggan. Penelitian ini bertujuan untuk mengembangkan aplikasi yang dapat memprediksi umur transformator secara akurat menggunakan metode Deep Learning-LSTM. LSTM adalah metode yang dapat digunakan untuk mempelajari suatu pola pada data deret waktu. Data yang digunakan dalam penelitian ini bersumber dari 25 unit transformator yang meliputi data dari sensor arus, tegangan, dan suhu. Analisis performa yang digunakan untuk mengukur kinerja LSTM adalah Root Mean Squared Error (RMSE) dan Squared Correlation (SC). Selain LSTM, penelitian ini juga menerapkan algoritma Multilayer Perceptron, Linear Regression, dan Gradient Boosting Regressor sebagai algoritma pembanding. Hasil eksperimen menunjukkan bahwa LSTM mempunyai kinerja yang sangat bagus setelah dilakukan pencarian komposisi data, seleksi fitur menggunakan algoritma KBest dan melakukan percobaan beberapa variasi parameter. Hasil penelitian menunjukkan bahwa metode Deep Learning-LSTM mempunyai kinerja yang lebih baik daripada 3 algoritma lain yaitu nilai RMSE=0,0004 dan nilai Squared Correlation=0,9690.
\end{abstract}

Kata kunci: Prediksi, Transformator, Deep Learning, LSTM

\section{DEEP LEARNING-LSTM ALGORITHM FOR POWER TRANSFORMER LIFETIME PREDICTION}

\begin{abstract}
The quality and availability of the electricity supply is very important. Failures in the transformer cause power outages which can reduce the quality of service to customers. Therefore, knowledge of transformer life is very important to avoid sudden transformer damage which can reduce the quality of service to customers. This study aims to develop applications that can predict transformer life accurately using the Deep Learning-LSTM method. LSTM is a method that can be used to study a pattern in time series data. The data used in this research comes from 25 transformer units which include data from current, voltage, and temperature sensors. The performance analysis used to measure LSTM performance is Root Mean Squared Error (RMSE) and Squared Correlation (SC). Apart from LSTM, this research also applies the Multilayer Perceptron algorithm, Linear Regression, and Gradient Boosting Regressor as a comparison algorithm. The experimental results show that LSTM has a very good performance after searching for the composition of the data, selecting features using the KBest algorithm and experimenting with several parameter variations. The results showed that the Deep Learning-LSTM method had better performance than the other 3 algorithms, namely the value of RMSE $=0.0004$ and the value of Squared Correlation $=0.9690$
\end{abstract}

Keywords: Prediction, Power Transformator, Deep Learning, LSTM.

\section{PENDAHULUAN}

Perkembangan teknologi informasi saat ini sangat berguna untuk semua aspek bidang pekerjaan.
Terutama teknologi AI telah banyak diterapkan dalam kehidupan sehari-hari seperti adanya smart home, sistem pendukung keputusan, pembacaan sensor. Tanpa disadari teknologi informasi menjadi 
salah satu kebutuhan utama dalam pengembangan bisnis (Jahromi and R. Piercy, 2019). Sensor, wireless dan teknologi persuasif menjadi sebuah inovasi model bisnis yang telah berkembang pesat dan sangat potensial (Valter et al., 2017). Jaminan kualitas penyaluran energi kepada pelanggan menjadi sangat penting bagi penyedia energi listrik. Ini harus mencakup kesehatan peralatan yang digunakan untuk menyediakan energi kepada pelanggan. Trasnformator distribusi adalah peralatan yang paling dekat dengan beban listrik (Tjahjono et al., 2019).

Strategi pemeliharaan peralatan saat ini terbagi menjadi tiga kategori utama. Yang pertama adalah 'run-to-failure'. Dalam kategori ini, intervensi terjadi hanya setelah transformator gagal. Kategori kedua adalah pemeliharaan preventif. Pada tahap ini, tindakan pemeliharaan dilakukan sesuai dengan yang direncanakan. Kategori terakhir, pemeliharaan prediktif adalah paling hemat biaya. Upaya pemeliharaan prediktif untuk menilai kondisi kesehatan setiap perangkat. Ini memungkinkan untuk deteksi lanjutan dari kegagalan yang tertunda (Gultom et al., 2017)

Sistem pemantauan pada transformator dapat memudahkan pengguna dalam mendeteksi peristiwa atau mengembangkan kesalahan pada transformator yang dapat mengganggu pengoperasiannya. Ini mengarah pada manajemen aset yang lebih efisien (Ceferin et al., 2017). Prediksi umur selalu menjadi tugas yang menantang karena beberapa alasan, misalnya representasi fitur yang tidak akurat yang disebabkan oleh noise, variasi akhir masa pakai dan ketidakpastian prediksi lainnya (Ma \& Mao, 2019).

Deep Learning merupakan sebuah teknologi yang digadang-gadang menjadi salah satu teknologi terpenting setelah internet dan sering digambarkan sebagai teknologi yang akan mengantikan posisi manusia di lapangan pekerjaa (Lecun et al., 2015). LSTM merupakan salah satu jenis Recurrent Neural Network. LSTM dapat memiliki kemampuan mempelajari data di mana dalam setiap neuron LSTM memiliki beberapa gerbang yang mengatur memori dari setiap neuron itu sendiri (Sakinah et al., 2019). Dengan menggunakan hasil prediksi umur trafo diharapkan dapat membuat keputusan lebih cerdas terkait kapan dan di mana perbaikan akan dilakukan. Keputusan cerdas tersebut dapat mengurangi biaya operasional dikarenakan akan dapat disusun rencana perbaikan yang lebih baik (Diwyacitta et al., 2017).

Pada penelitian ini dijabarkan mengenai penggunaaan algoritma Deep Learning dalam melakukan prediksi umur transformator. Deep Learning yang digunakan pada penelitian ini menggunakan Long Short Term Memory Neural Network (LSTM). LSTM banyak digunakan untuk mengolah teks, video, dan data deret waktu (Azzouni and Pujolle, 2018). Parameter pada penelitian ini menggunakan tegangan, arus dan suhu pada trafo. Analisis performa yang digunakan menggunakan nilai Root Mean Squared Error (RMSE) yang merupakan tingkat kesalahan hasil prediksi dan nilai Squared Correlation (SC) yang menggambarkan nilai proporsi variasi dalam attribut yang dikaitkan dengan hasil prediksi.

\section{METODE PENELITIAN}

Proses penelitian dibagi menjadi beberapa fase utama. Fase pertama adalah pengumpulan teori terkait transformator serta algoritma yang digunakan. Tahapan selanjutnya pengumpulan dataset yang digunakan dalam penelitian. Mendapatkan fitur terbaik dan nilai parameter optimal data kemudian digunakan untuk pelatihan dan pengujian. Tahapan terakhir mencari penelitian terkait dengan topik penelitian.

\subsection{Transformator}

Transformator merupakan alat yang berfungsi untuk dapat memindahkan energi listrik arus bolakbalik dari suatu rangkaian ke rangkaian yang lain. Tegangan yang dihasilkan dapat lebih besar atau lebih kecil.

Transformator beroperasi berdasarkan rangkaian magnetik dan belitan yang terdiri beberapa belitan (Gambar 1), secara induksi elektromagnetik, mentransformasikan daya (arus dan tegangan) sistem AC ke sistem arus dan tegangan lain pada frekuensi yang sama (Jahromi, et al., 2019).

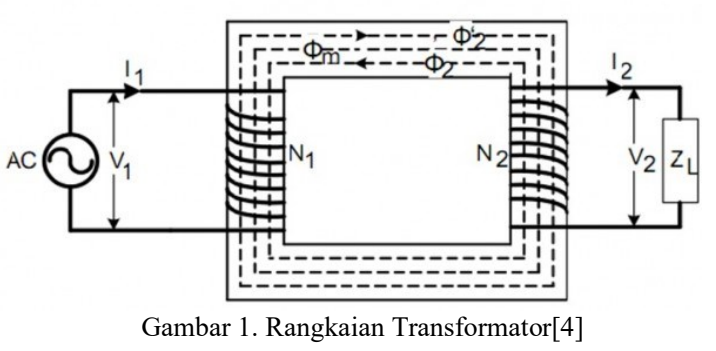

\subsection{Selisih Suhu Hotspot dengan Suhu Top Oil}

$\Delta \theta_{c}$ (Delta Suhu Hotspot Top Oil) adalah selisih antara suhu hotspot dengan suhu top oil, dapat dihitung dengan persamaan 1 (Gultom, 2017).

$\Delta \theta \mathrm{c} \quad=\left(\Delta \theta \mathrm{cr}-\Delta \theta_{\mathrm{br}}\right) \mathrm{K}^{2 \mathrm{y}}$

Dengan

$$
\begin{aligned}
& \Delta \theta \mathrm{cr} \quad=78^{\circ} \mathrm{C} \\
& \mathrm{y}=\text { konstanta } \\
& \mathrm{y}=0,8 \text { (ONAN dan ONAF) } \\
& \mathrm{y}=0,9 \text { (OFAF dan OF WF) } \\
& \Delta \theta_{\mathrm{br}}=\text { suhu }
\end{aligned}
$$

Untuk $\Delta \theta_{\mathrm{br}}=55^{\circ} \mathrm{C}$ untuk ON, $\Delta \theta_{\mathrm{br}}=40^{\circ} \mathrm{C}$ untuk $\mathrm{OF}$

\subsection{Nilai Relatif dari Umur Pemakaian}

Nilai relative dapat dihitung dengan menggunakan rumusan dari Montsinger pada suhu $\Delta \theta_{c}$, lalu dibanding dengan nilai normal dari umur pemakaian pada suhu $\Delta \theta_{\mathrm{cr}}$. Detil rumusan yang digunakan terdapat pada persamaan 2 dan 3 (Gultom, 2017). 
$\mathrm{V}=\left[\frac{\text { Laju penggunaan umur saat } \Delta \theta_{\mathrm{c}}}{\text { Laju penggunaan umur saat } \Delta \theta_{\mathrm{cr}}}\right]$

$\mathrm{V}=2^{\left(\Delta \theta_{\mathrm{c}}-\Delta \theta_{\mathrm{cr}}\right)} / 6$

Dengan :

$\mathrm{V}=$ nilai relative dari umur pakai

$\Delta \theta_{\mathrm{cr}} \quad=98^{\circ} \mathrm{C}$ menurut publikasi IEC 76(1967).

\subsection{Pengurangan Umur Transformator}

Besarnya susut umur dari sebuah transformator dapat dihitung dengan menggunakan persamaan 4 (Gultom, 2017).

$\mathrm{L}=\sum_{\mathrm{n}=1}^{\mathrm{N}} \mathrm{V}_{\mathrm{n}}$

Di mana :

$\mathrm{L}=$ loss of life calculation

$\mathrm{V}_{\mathrm{n}} \quad=$ nilai dari umur pemakaian pada waktu $\mathrm{n}$

$\mathrm{n} \quad=$ waktu ke(jam)

\subsection{Perkiraan Umur Transformator}

Nilai pembebanan berubah-ubah setiap hari menyebabkan kesulitan dalam menentukan pola pembebanan hariannya. Maka diasumsikan setiap hari merupakan pembebanan harian. Sehingga didapatkan rumus untuk menentukan perkiraan sisa umur transformator terdapat pada persamaan 5 .

Sisa waktu pakai $=\left[\frac{8760-(\mathrm{Lx} 365)}{8760}\right] \times$ umur dasar

Di mana :

$\begin{array}{ll}\text { Umur dasar } & =30 \text { tahun } \\ 8760 & =\text { Jam }(1 \text { tahun }) \\ 365 & =\text { Hari }(1 \text { tahun })\end{array}$

\subsection{Linear Regression}

Regresi adalah metode analisis statistik untuk mengidentifikasi hubungan antar variabel. Hubungannya dapat dikenali antara variabel dependen dan independen. Itu dapat dijelaskan menggunakan fungsi distribusi probabilitas (S, et al., 2016) digambarkan pada gambar 2. Linear Regression (Montgomery, et al., 2016) adalah prediksi yang paling umum model untuk mengidentifikasi hubungan antar variabel. Selain dari tipe data univariat atau multivariate dari konsep linier.

$\mathrm{Y}=\mathrm{a}+\mathrm{b} * \mathrm{X}$

Di mana:

$\mathrm{Y}=$ variable bebas

$\mathrm{X}=$ variable independen

$\mathrm{a}=$ intercept

$\mathrm{b}=$ slope (koefisien dari regresi)

\subsection{Multilayer Perceptron}

Multilayer Perceptron adalah jaringan neuron sederhana yang disebut perceptrons. Konsep dasar dari perceptron tunggal diperkenalkan oleh
Rosenblatt pada tahun 1958. Perceptron menghitung output tunggal dari beberapa input bernilai nyata dengan membentuk kombinasi linear sesuai dengan bobot inputnya dan kemudian mungkin menempatkan output melalui beberapa fungsi aktivasi nonlinier (Jitendra, et al., 2017). Secara matematis ini dapat ditulis pada persamaan 7 .

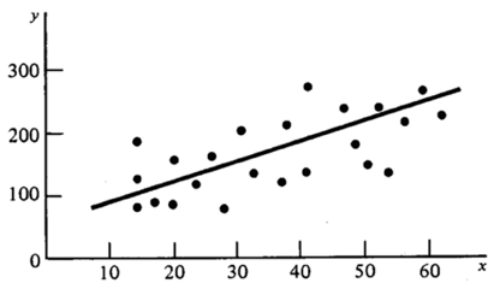

Gambar 2. Metode Linear Regression

$\mathrm{y}=\varphi\left(\sum_{i=1}^{n} w_{i} \cdot x_{i}+\mathrm{b}\right)=\varphi\left(w^{T} x+b\right)$

di mana $\mathrm{w}$ menunjukkan vektor bobot, $\mathrm{x}$ adalah vektor input, $\mathrm{b}$ adalah bias dan $\varphi$ adalah fungsi aktivasi. Grafik aliran sinyal dari operasi ini ditunjukkan pada gambar 3. Perceptron Rosenblatt asli menggunakan fungsi langkah Heaviside sebagai fungsi aktivasi $\varphi$. Saat ini, dan terutama di jaringan multilayer, fungsi aktivasi sering dipilih sebagai sigmoid logistic atau garis singgung hiperbolik. Fungsi-fungsi ini digunakan karena mereka secara matematis nyaman dan dekat dengan linier dekat asal sementara menjenuhkan agak cepat ketika menjauh dari asal. Hal ini memungkinkan jaringan MLP untuk memodelkan pemetaan yang baik secara kuat dan agak nonlinier.

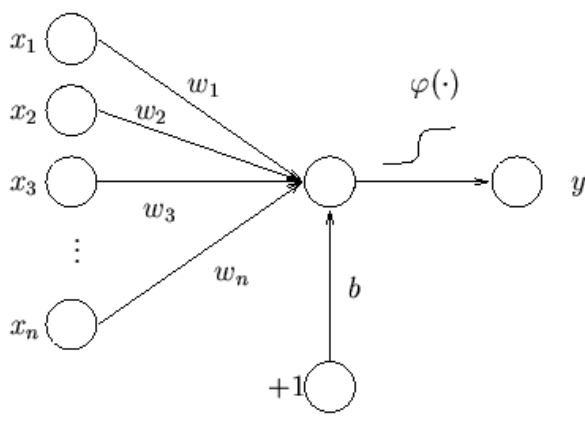

Gambar 3. Struktur MLP (Jitendra, et al., 2017)

\subsection{Long Short Term Memory}

Deep Learning atau pembelajaran terstruktur mendalam dapat didefinisikan sebagai jenis jaringan saraf khusus yang terdiri dari beberapa lapisan. Jaringan ini lebih baik daripada jaringan saraf tradisional dalam menyimpan informasi dari acara sebelumnya (Hochreiter \& Schmidhuber, 2017). Jaringan saraf berulang (RNN) adalah salah satu mesin yang memiliki kombinasi jaringan dalam loop. Jaringan loop memungkinkan informasi tetap ada. 
Setiap jaringan dalam loop tersebut mengambil masukan dan informasi dari jaringan sebelumnya, melakukan operasi yang ditentukan dan menghasilkan keluaran bersama dengan meneruskan informasi ke jaringan berikutnya (Hochreiter \& Schmidhuber, 2017).

Long Short Term Memory Neural Network (LSTM) merupakan salah satu jenis RNN. LSTM memiliki kemampuan untuk mempelajari data yang harus digunakan atau diabaikan, proses ini terjadi pada setiap neuron (Sakinah, et al., 2019). LSTM banyak digunakan untuk mengolah teks, video, dan data deret waktu (Azzouni \& Pujolle, 2017). Hal ini berdasarkan lebih banyak informasi sebelumnya dapat mempengaruhi akurasi model, LSTM menjadi pilihan penggunaan yang wajar. Modul LSTM yang disebut modul berulang memiliki empat modul lapisan jaringan saraf yang saling berinteraksi ditunjukkan pada gambar 4 .

Simbol $\pi$ dan $\Sigma$ mewakili elemen perkalian bijak dan penjumlahan masing-masing. Operasi penggabungan diwakili oleh simbol $(\bullet)$ poin. Itu komponen dasar LSTM adalah status sel, sebuah baris yang berjalan dari memori dari blok sebelumnya $\left(S_{t}-1\right)$ ke memori blok saat ini $\left(S_{t}\right)$. Ini memungkinkan informasi mengalir lurus ke bawah. Jaringan dapat menentukan jumlah informasi sebelumnya mengalir. Itu dikendalikan melalui lapisan pertama $(\sigma 1)$. Operasi yang dilakukan oleh lapisan ini diberikan (Jitendra, et al., 2017).

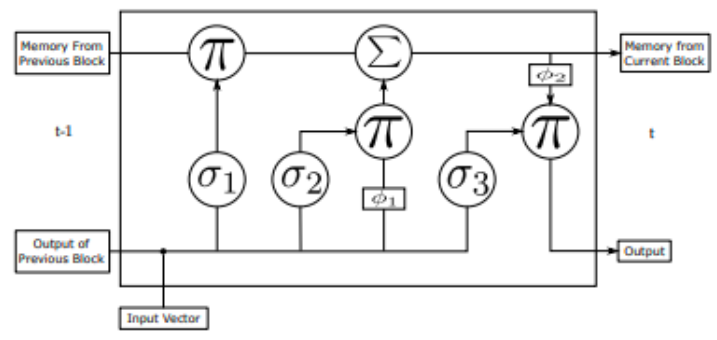

Gambar 4. Perulangan Modul LSTM[7]

\subsection{Deep Learning}

Deep Learning merupakan suatu algoritma yang pada proses pengolahannya menggunakan sejumlah hidden layer, lalu pada proses perhitungan nilai output menggunakan transformasi linier. Pada Deep Learning terdapat sebuah fitur yang mampu bekerja secara otomatis dalam mengekstraksi data. Dapat dikatakan algoritma ini dapat mengolah fitur secara baik dalam memecahkan suatu masalah. Di dalama dunia kecerdasan buatan hal tersebut menjadi hal yang sangat penting dalam proses mengurangi beban pemrogaman. Algortima ini dapat digunakan untuk memecahkan dengan metode supervised, unsupervised, dan supervised (Dong \& Grumbach, 2018; E. B, \& M. M., 2015).

Deep Learning memiliki kemampuan untuk menemukan struktur rumit dari sebuah data yang besar dengan metode backpropagation (Leecun, et al., 2015). Ilustrasi terdapat pada gambar 5. Deep Learning memiliki beberapa properti yang mengukuhkan statusnya sebagai revolusi AI. Kita mungkin tidak menggunakan Neural Network dua dekade dari sekarang, namun apapun yang kita gunakan akan secara langsung mewarisi dari pembelajaran mendalam modern dan konsep intinya. Properti penting ini secara luas dapat diurutkan menjadi tiga kategori:

- Kesederhanaan

Deep Learning menghilangkan kebutuhan akan rekayasa fitur, menggantikan pipeline yang rumit, rapuh, dan banyak rekayasa dengan model sederhana yang dapat dilatih secara menyeluruh yang biasanya dibuat hanya menggunakan lima atau enam operasi tensor yang berbeda.

- Skalabilitas

Deep learning sangat cocok untuk paralelisasi pada GPU atau TPU, sehingga dapat memanfaatkan sepenuhnya hukum Moore.

- Keserbagunaan dan kegunaan kembali

Tidak seperti banyak pendekatan pembelajaran mesin sebelumnya, model Deep Learning dapat dilatih pada data tambahan tanpa memulai ulang dari awal, membuatnya layak untuk pembelajaran online berkelanjutan (Chollet, 2018).

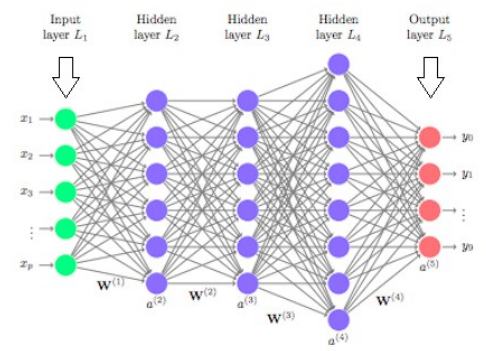

Gambar 5. Iustrasi Deep Learning[8]

\subsection{Dataset}

Pada tahap implementasi ini menggunakan dataset transformator distribusi di mana dataset ini bersifat deret waktu. Data didapatkan berdasarkan historis dari 25 unit transformator, di mana dataset akan diselesaikan dengan pendekatan regresi.

Dataset Transformator ini terdiri dari 24 kolom dan 12480 data. Setiap baris adalah sebuah data yang diambil selama satu siklus operasional tunggal, setiap kolom adalah variabel yang berbeda. Kolom tersebut terdiri dari Kode trafo, Tanggal, Tegangan pada R(VR), Tegangan pada S (VS), Arus pada R(IR), Arus pada S(IS), Arus pada T(IT), PF-R, PF-S, PF-T, Load_Factor, Energi, Unbalanced_Load, Suhu, d, Pendingin_x, Pendingin_y, Delta_b, Delta_cr, Delta_c, n, V, L, Umur Dasar, Prediksi_umur. Tābel 1 menampilkan contoh dari dataset yang digunakan. 
Table 1. Dataset Transformator

\begin{tabular}{|c|c|c|c|c|c|c|c|}
\hline ID & Tgl & VR & $\ldots$ & V & $\mathbf{L}$ & $\begin{array}{l}\text { Umur } \\
\text { dasar }\end{array}$ & Umur \\
\hline & $01 / 0$ & & & 0.0 & 5.2 & & \\
\hline 282 & $5 / 17$ & 211 & & 014 & 1 & 30 & 23 \\
\hline & $02 / 0$ & & ... & 0.0 & 5.3 & & \\
\hline 282 & $5 / 17$ & 211 & & 015 & 3 & 30 & 23 \\
\hline$\cdots$ & $\ldots$ & $\ldots$ & $\ldots$ & $\ldots$ & $\ldots$ & $\ldots$ & $\ldots$ \\
\hline 450 & $\begin{array}{l}01 / 0 \\
5 / 17\end{array}$ & 221 & $\ldots$ & $\begin{array}{l}0.0 \\
058\end{array}$ & $\begin{array}{l}34 . \\
22\end{array}$ & 30 & 24 \\
\hline
\end{tabular}

Visualisasi sebaran data yang terdapat pada Gambar 6
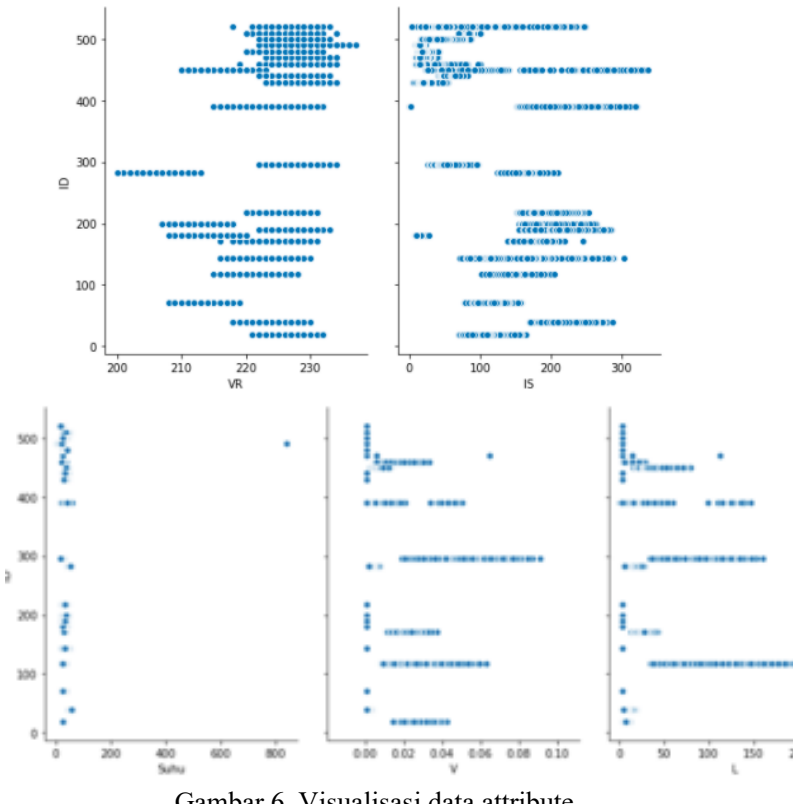

\subsection{Desain Perangkat Lunak}

Pada pengujian kali ini akan di lakukan dengan menggunakan Deep Learning dengan menggunakan model LSTM serta MLP, Linear Regression dan Gradient Boosting Regressor sebagai algoritma pembanding. Adapun untuk desain sistem dari penelitian ini terdapat pada Gambar .

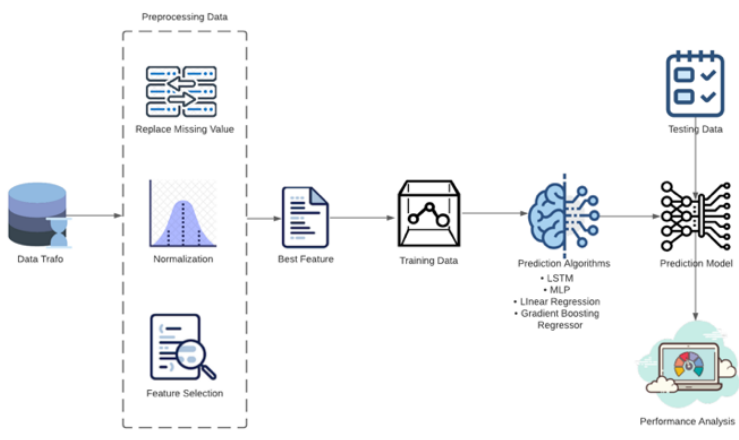

Gambar 7. Desain Sistem

Sebelum masuk ke proses pengujian. Data transformator terlebih dahulu harus dilakukan pemprosesan data di mana langkah ini sangat berguna untuk pembersihan data sebelum dilanjutkan ke proses training data. Selain itu diadakan juga proses seleksi fitur di mana proses ini berfungsi untuk mendeteksi attribut yang sangat berpengaruh dalam proses prediksi kedepannya.

Pengujian akan dilakukan dengan beberapa algoritma dan pada proses validasi dataset menggunakan metode $k$-fold cross validation, di mana fungsi ini memiliki dua subproses. Subproses train data digunakan untuk mempelajari atau membangun model. Model yang dilatih kemudian diterapkan dalam subproses test-data. Performa model juga diukur selama tahap pengujian.

\subsection{Ujicoba Dataset dan Algoritma}

Penelitian menggunakan nilai RMSE sebagai indikator keberhasilan dalam proses pengujian hasil penelitian. Dimana Root Mean Squared Error (RMSE) adalah salah satu metode pengukuran dengan cara menghitung perbedaan nilai prediksi sebuah model sebagai estimasi atas nilai data yang diobservasi. Persentase dari akar kesalahan kuadrat rata-rata (\%RMSE) dapat mengatasi hal ini, dan didefinisikan pada persamaan 7 dan 8 .

$\%$ RSME $=\frac{\text { RSME }}{\mathrm{T}_{1}} \times 100 \%$

Di mana:

$\mathrm{T}_{1}=\frac{1}{\mathrm{~N} \cdot(\mathrm{N}-1)} \sum_{\mathrm{i}} \sum_{\mathrm{d}} \mathrm{T}_{\mathrm{u}}$ untuk $\mathrm{i} \neq \mathrm{d}$

Nilai RSME dan \%RSME merepresentasikan hasil estimasi model yang dihasilkan. Semakin kecil nilai RMSE, maka semakin akurat pula hasil prediksi yang dihasilkan.

\subsubsection{Pengujian Komposisi Dataset}

Penelitian ini akan menggunakan teknik $K$ Fold-Cross Validation dalam proses menentukan komposisi data yang berfungsi untuk menguji keakuratan sebuah model yang dihasilkan. Proses ini melibatkan fold 6 s.d 10. Di mana setiap proses training, testing dan validasi dilakakukan sebanyak 6 s/d 10 lipatan secara terus menerus. Adapaun pada proses pengujian komposisi dataset ini masih menggunakan parameter standart dari Deep Learning-LSTM.

\subsubsection{Seleksi fitur}

Seleksi fitur adalah masalah krusial dalam pembelajaran mesin yang efisien, dan juga berkontribusi besar pada kemampuan menjelaskan keputusan yang dihasilkan mesin (Wang, et al., 2020). Seleksi fitur merupakan proses memilih fitur yang tepat untuk digunakan. Proses ini bertujuan untuk menyederhanakan proses, meningkatkan akurasi dari sebuah algoritma, serta dapat mengetahui fitur yang paling berpengaruh dalam meningkatkan hasil akurasi. Pemilihan metode Select KBest pada penelitian ini bertujuan menyederhanakan banyaknya 
attribut yang ada pada dataset transformator. Adapun pseudocode dari proses ini terdapat pada Tabel 2.

Tabel 2. Pseudocode Proses Seleksi Fitur dengan KBest

\begin{tabular}{|c|c|}
\hline Urutan & Proses \\
\hline Step-1 & Panggil dataset trafo. \\
\hline Step-2 & Bagi data menjadi data pelatihan dan pengujian. \\
\hline Step-3 & $\begin{array}{l}\text { Panggil fungsi library SelectKBest, panggil } \\
\text { f_regression untuk bagian skor dan masukkan } \\
\text { nilai K. Disini kita masukkan seluruh fitur. }\end{array}$ \\
\hline Step-4 & $\begin{array}{l}\text { Buat perulangan sebanyak nilai } \mathrm{k} \text { yang sudah } \\
\text { dimasukkan. }\end{array}$ \\
\hline Step-5 & Cetak hasil dari setiap fitur. \\
\hline
\end{tabular}

\subsubsection{Skenario Pengujian Algoritma}

Adapun untuk skema pengujiannya terdapat 4 skenario pengujian yaitu algoritma Multilayer Perceptron(MLP), Deep Learning(LSTM), Linear Regression(LR), Gradient Boosting Regressor(GBR) seperti pada Tabel 3 .

Tabel 3. Skenario Pengujian Algoritma

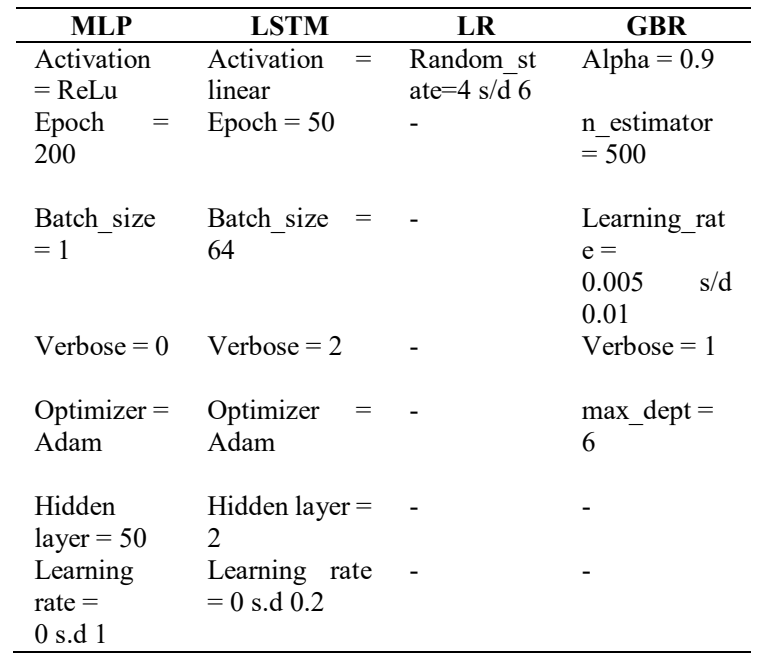

Pada penelitian kali ini akan difokuskan pada algoritma Deep Learning. Adapun untuk pseudocode dari Algoritma ini terpadapat pada Tabel 4.

Tabel 4. Pseudocode Algoritma Deep Learning

\begin{tabular}{ll}
\hline Urutan & Proses \\
\hline Step-1 & Panggil dataset trafo. \\
Step-2 & Lakukan normalisasi dan scaling feature \\
Step-3 & Replace missing value \\
Step-4 & Buat sebuah sequence sebesar 100 \\
Step-5 & Masukkan metode validasi pada dataset \\
Step-6 & Gunakan window size = seq len - 1 \\
Step-7 & Masukkan parameter sesuai dengan scenario. \\
Step-8 & Compile model dengan tipe loss= \\
& mean_squared_error dan optimizer=adam \\
Step-9 & Buat prediksi berdasarkan test data dan cetak hasil
\end{tabular}

\subsection{Penelitian Terkait}

Penelitian mengenai prediksi umur transformator telah dilakukan dengan berbagai macam metode dan parameter. Nuno pada penelitannya mengestimasikan sisa umur dari transformator menggunakan model indeks kesehatan dengan paper insulation (De and Do, 2018). Alhaytham melakukan penelitian dengan menggunakan sampel minyak dan load factor sebagai parameter dalam memprediksi tingkat kesehatan suatu transformator, dan Machine Learning dipilih dalam metode penelitiannya (Alqudsi and El-Hag, 2019). Yolla menggunakan suhu, load factor, dan bahan isolasi belitan sebagai parameter dalam memperkirakan umur transformator. Analisa tren linear digunakan dalam metode penelitian tersebut (Rizki and Ervianto, 2019).

Deep Learning pun juga banyak diterapkan dalam berbagai kasus prediksi yang memiliki jumlah data yang besar. Khususnya untuk LSTM, memiliki kemampuan untuk menangani data besar bertipe deret waktu. G. Sateesh menggunakan Deep Learning berbasis CNN dalam memecahkan kasus prediksi sisa umur dari sebuah mesin pesawat (Babu et al., 2016). Xinjuan melakukan prediksi kualitas udara pada suatu daerah dengan menggunakan algoritma LSTM-Kalman model (Song et al., 2019). Md. Arif melakukan prediksi harga saham dengan menggunakan LSTM kemudian dibandingkan dengan metode LSTM model Bi-Directional (Istiake Sunny et al., 2020).

\section{HASIL PEMBAHASAN}

Penelitian dilakukan pada perangkat computer i5 dengan kecepatan 1600 Mhz dengan kapasitas Memory 4GB. Python dengan Keras Library dipilih sebagai alat untuk mengimplementasi. Dataset yang digunakan adalah dataset transformator distribusi. Hal pertama yang dilakukan pada dataset tranformator adalakh melakukan menentukan komposisi data yang akan digunakan, lalu dilanjutkan proses seleksi fitur, di mana fitur tesebut ternyata menjadi fitur yang berpengaruh dalam proses prediksi umur dari transformator. Selanjutnya dilakukan proses pembelajaran menggunakan 4 jenis algoritma yaitu Deep Learning-LSTM, Multilayer Perceptron, Linear Regression dan Gradient Boosting Regressor sebagai algoritma pembanding. Hasil percobaan menggunakan 4 jenis algoritma tersebut dijelaskan pada bagian berikut ini.

\subsection{Hasil Pengujian Komposisi Dataset}

Deep Learning dapat menghasilkan nilai prediksi yang memuaskan jika data yang digunakan untuk proses training (pembelajaran) berjumlah banyak dan parameter yang digunakan tepat. Sebelum menetapkan parameter untuk LSTM, dilakukan proses pengujian komposisi data. Tabel 5 berikut ini menjelaskan proses pembentukan model menggunakan $k$-fold cross validation di mana nilai $\mathrm{k}$ bervariasi dari 6-10. 
Table 5. Komposisi Dataset Fold 6 s.d 10

\begin{tabular}{ccccc}
\hline Fold & $\begin{array}{c}\text { Hidden } \\
\text { Layer }\end{array}$ & Epoch & $\begin{array}{c}\text { Training } \\
\text { Error }\end{array}$ & $\begin{array}{c}\text { Testing } \\
\text { Error }\end{array}$ \\
\hline 6 & 2 & 10 & 0,0235 & 0,0192 \\
7 & 2 & 10 & 0,0277 & 0,0166 \\
8 & 2 & 10 & 0,0251 & 0,210 \\
9 & 2 & 10 & 0,0155 & 0,0250 \\
10 & 2 & 10 & 0,0137 & 0,0219 \\
\hline
\end{tabular}

Dari 5 kombinasi fold yang ditunjukkan pada tabel 5 hasil terbaik didapatkan pada saat menggunakan fold bernilai 10 yang menghasilkan nilai eror 0,0137 pada training data dan 0,0219 pada testing data. Oleh karena itu, semua percobaan berikutnya akan menggunakan $\mathrm{k}=10$.

\subsection{Hasil Seleksi Fitur}

Dataset transformator memiliki 24 attribut kemudian dilakukan proses seleksi fitur dengan metode KBest. Di mana proses KBest untuk mengoptimalkan kinerja suatu model dengan memilih fitur-fitur yang memiliki skor signifikan. Berdasarkan tabel 2 maka proses seleksi fitur menghasilkan output seperti pada Tabel 6 .

\begin{tabular}{|c|c|c|}
\hline No & Fitur & Nilai Skor \\
\hline 1 & 0 & 0.0388 \\
\hline 2 & 1 & 98.5349 \\
\hline 3 & 2 & 55.4718 \\
\hline 4 & 3 & 40.6785 \\
\hline 5 & 4 & 23.9592 \\
\hline 6 & 5 & 70.5893 \\
\hline 7 & 6 & 41.8381 \\
\hline 8 & 7 & 34.4428 \\
\hline 9 & 8 & 0.1485 \\
\hline 10 & 9 & 41.5037 \\
\hline 11 & 10 & 9.0395 \\
\hline 12 & 11 & 461.5626 \\
\hline 13 & 12 & 257.6368 \\
\hline 14 & 13 & 200.1730 \\
\hline 15 & 14 & 0.0000 \\
\hline 16 & 15 & nan \\
\hline 17 & 16 & 0.0000 \\
\hline 18 & 17 & 48.4563 \\
\hline 19 & 18 & nan \\
\hline 20 & 19 & 48.8796 \\
\hline 21 & 20 & 40.4754 \\
\hline 22 & 21 & 200.0300 \\
\hline 23 & 22 & 329.5501 \\
\hline 24 & 23 & Nan \\
\hline
\end{tabular}

Mengacu hasil dari table 6 terlihat bahwa dari 24 attribut menghasilkan skor yang beragam. Adapaun detil fitur dari Tabel 6 adalah fitur 1(Tanggal), fitur 2(VR), fitur 3(VS), fitur 4(IR), fitur 5(IS), fitur 6(IT), fitur 7(PF-R), fitur 8(PF-R), fitur 9(PF-T), fitur 10(Load Factor), fitur 11(Energi), fitur 12(Unbalanced Load), fitur 13(Suhu), fitur 14(d), fitur15(Pendingin_x), fitur 16(Pendingin_y), fitur 17(Delta b), fitur 18(Delta cr), fitur 19(Delta_c), fitur 20(n), fitur 21(V), fitur 22(L), fitur 23(Umur dasar). Pada Gambar 8 ditampilkan grafik hasil seleksi fitur yang telah dilakukan.

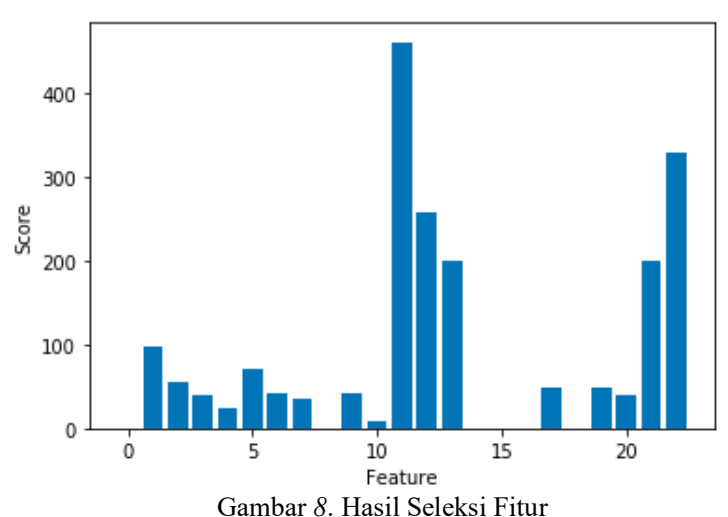

Dari gambar 3 menunjukkan ada 5 fitur bernilai sangat kuat dalam mempengaruhi hasil prediksi umur dari transformator. Namun pada penelitian ini diputuskan untuk menambahkan 2 fitur yaitu fitur 1(Tanggal) dan fitur 5(IS). Hal ini dikarenakan dalam menggunakan algoritma Deep Learning-LSTM attribut tanggal dan arus pada $\mathrm{S}(\mathrm{IS})$ sangat diperlukan. Sehingga dalam penelitian ini diputuskan menggunakan 7 fitur tertinggi. Adapun ketujuh fitur itu yaitu: fitur 1(Tanggal), fitur 5(IS), fitur 11(Energi), fitur 12(Unbalanced Load), fitur 13(Suhu), fitur 21(V), fitur 22(L). Energi merupakan kekuatan dari transformator, suhu merupakan keadaan suhu dari transformator, $\mathrm{V}$ merupakan nilai relative pemakaian, dan L merupakan pengurangan umur pada transformator.

\subsection{Keluaran Performa Algoritma}

Implementasi algoritma untuk memprediksi umur transformator menggunakan algoritma Deep Learning-LSTM, Multilayer Perceptron, Linear Regression, dan Gradient Boosting Regressor sebagai pembanding. Berikut merupakan keluaran dari hasil penelitian.

\subsubsection{Deep Learning-LSTM}

Algoritma Deep Learning-LSTM merupakan algoritma utama yang dilakukan pada penelitian ini. Skenario pengerjaan algoritma ini terdapat pada Tabel 4. Analisis performa yang dihasilkan pada penelitian ini menggunakan RMSE dan SC. Nilai RSME yang merupakan representasi nilai tingkat kesalahan prediksi pada metode LSTM menghasilkan 1,1823 dan $\mathrm{SC}=0,4218$. Nilai-nilai tersebut dihasilkan pada saat sebelum dilakukan proses seleksi fitur. Hasil dari proses seleksi fitur dengan metode KBest merujuk pada skenario pengujian pada Tabel 2 dan untuk hasilnya dilihat pada Tabel 11. Di mana hasil paling baik pada saat menggunakan nilai learning rate $=0,1$. Hasil pengujian beberapa learning rate dapat dilihat pada Tabel 7. Nilai RSME 0,0004 dan nilai SC 0,9690. Hasil tersebut menunjukkan bahwa algoritma Deep Learning-LSTM menghasilkan nilai tingkat kesalahan prediksi (RMSE) yang lebih kecil dan nilai SC yang lebih besar setelah dilakukan proses seleksi fitur dan melakukan pengaturan pada nilai learning rate. 
Tabel 7. Hasil Algoritma Deep Learning-LSTM

\begin{tabular}{ccc}
\hline Learning Rate & RSME & SC \\
\hline 0 & 0,0010 & 0,9313 \\
0,1 & 0,0004 & 0,9690 \\
0,2 & 0,0006 & 0,9595 \\
\hline
\end{tabular}

Adapun Output historis loss yang dihasilkan selama proses pembelajaran model yang dilakukan pada train dan test data pada saat menggunakan skenario dari Tabel 3 dan nilai learning rate 0,1 dapat dilihat pada gambar 9 .

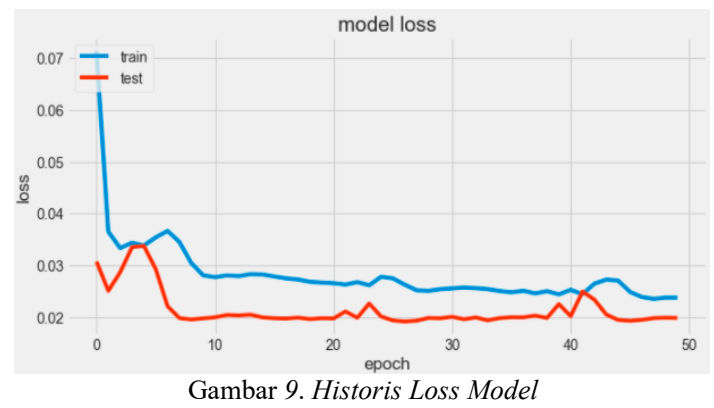

\subsubsection{Algoritma Pembanding}

Penelitian ini juga melakukan proses perbandingan dengan beberapa algoritma prediksi lainnya seperti: algoritma Multilayer Perceptron, Linear Regression dan Gradient Boosting Regressor. Hal ini dimaksudkan untuk mengetahui sejauh mana performa algoritma Deep Learning-LSTM dibandingkan dengan algoritma prediksi lainnya.

\section{a. Multilayer Perceptron(MLP)}

Mengacu pada skenario pengujian pada Tabel 3. Tabel 8 menunjukkan hasil pengujian menggunakan learning rate dari $0 \mathrm{~s} / \mathrm{d} 1$ dengan algoritma Multilayer Perceptron. Hasil RMSE dan SC terbaik pada saat menggunakan learning rate 1 dengan nilai RSME 3,144 dan SC 0,681.

Tabel 8. Pengujian Algoritma MLP

\begin{tabular}{ccc}
\hline Learning Rate & RMSE & SC \\
\hline 0 & 4,291 & 0,407 \\
0,5 & 3,772 & 0,542 \\
1 & 3,144 & 0,681 \\
\hline
\end{tabular}

\section{b. Linear Regression}

Mengacu pada skenario pengujian pada Tabel 3. Tabel 9 menunjukkan hasil pengujian menggunakan random state dari 2 s/d 6 dengan algoritma Linear Regression. Hasil RMSE dan SC terbaik pada saat menggunakan random state 6 yaitu $\mathrm{RMSE}=1,0305$ dan $\mathrm{SC}=0,703$.

Tabel 9. Pengujian Algoritma Linear Regression

\begin{tabular}{ccc}
\hline Random State & RMSE & SC \\
\hline 2 & 8,1530 & 0,627 \\
4 & 4,6346 & 0,599 \\
6 & 1,0305 & 0,703 \\
\hline
\end{tabular}

\section{c. Gradient Boosting Regressor}

Mengacu pada skenario pengujian pada Tabel 3 . Tabel 10 menunjukkan hasil pengujian menggunakan learning rate dari 0,005 s/d 0,1 dengan algoritma Gradient Boosting Regressor. Hasil RMSE dan SC terbaik pada saat menggunakan learning rate 0,1 dengan nilai $\mathrm{RMSE}=0,0414$ dan $\mathrm{SC}=0,9348$.

Tabel 10. Pengujian Algoritma GBR

\begin{tabular}{ccc}
\hline Learning Rate & RMSE & SC \\
\hline 0,005 & 1,2072 & 0,8992 \\
0,05 & 0,9371 & 0,9208 \\
0,1 & 0,0414 & 0,9348 \\
\hline
\end{tabular}

Berdasarkan hasil pengujian yang dilakukan pada tabel 7, tabel 8, tabel 9 dan tabel 10. Hasil terbaik dari setiap algoritma kemudian diteruskan proses perbandingan antar algoritma yang terdapat pada tabel 11 .

Table 11. Hasil Deep Learning dengan Algoritma Pembanding

\begin{tabular}{lcccc}
\hline \multirow{2}{*}{ Algoritma } & \multicolumn{2}{c}{ Sebelum FS } & \multicolumn{2}{c}{ Setelah FS } \\
\cline { 2 - 5 } & RMSE & SC & RMSE & SC \\
\hline $\begin{array}{l}\text { Deep Learning- } \\
\text { LSTM }\end{array}$ & 1,1823 & 0,421 & 0,0004 & 0,9690 \\
MLP & 5,5306 & 0,3960 & 3,144 & 0,681 \\
$\begin{array}{l}\text { Linear } \\
\text { Regresion }\end{array}$ & 8,7330 & 0,3625 & 1,0305 & 0,703 \\
$\begin{array}{l}\text { Gradient } \\
\text { Boosting } \\
\text { Regressor }\end{array}$ & 2,3483 & 0,6329 & 0,0414 & 0,9348 \\
\hline
\end{tabular}

Tabel 11 tentang perbandingan antar algoritma menunjukkan Deep Learning-LSTM menghasilkan kinerja yang signifikan dalam menghasilkan nilai RMSE yang paling kecil dan nilai kolerasi (SC) yang lebih besar. Parameter yang digunakan adalah activation $=$ linear, epoch $=50$, batch_size $=64$, verbose $=2$, optimizer $=$ Adam, hidden layer $=2$ dan learning rate $=0,1$. Nilai dari $\mathrm{RMSE}=0,0004$ dan $\mathrm{SC}=0,9690$. Visualisasi prediksi dari algoritma Deep Learning-LSTM terdapat pada gambar 10 .

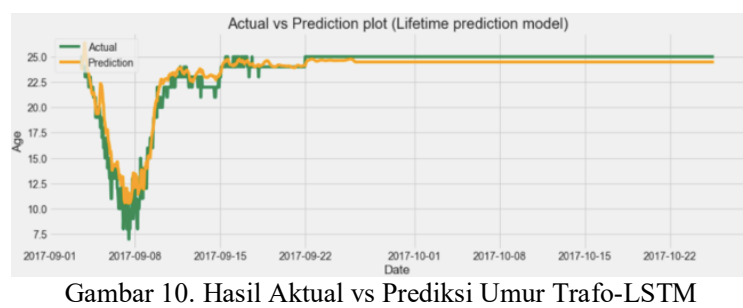

\section{KESIMPULAN}

Perangkat lunak yang diteliti pada penelitian ini menghasilkan hasil yang memuaskan pada dataset yang berasal dari rekaman dari 25 transformator. Metode KBest digunakan untuk proses seleksi fitur berhasil mengurangi jumlah fitur dari 24 menjadi 7 fitur yang paling penting dan relevan untuk 
memprediksi umur trafo yaitu tanggal, IS, energi, unbalanced load, suhu, V, dan L. Fitur-fitur ini kemudian diproses dengan empat algoritma mesin pembelajaran yaitu Multilayer Perceptron, Deep Learning-LSTM, Linear Regression dan Gradient Boosting Regressor. Hasil penelitian menunjukkan algoritma Deep Learning-LSTM dengan menggunakan parameter yaitu activation = linear, epoch $=50$, batch_size $=64$, verbose $=2$, optimizer $=$ Adam, hidden layer $=2$ dan learning rate $=0,1$ mempunyai kinerja yang lebih baik daripada 3 algoritma lain nilai RMSE $=0,0004$ dan nilai Squared Correlation $=0,9690$.

Pada penelitian selanjutnya perangkat lunak ini akan dilengkapi dengan IoT sehingga sistem dapat melakukan prediksi umur dari transformator secara realtime dan dapat mendeteksi secara dini jika terjadi kegagalan fungsi pada transformator. Hal ini tentu akan membantu dalam proses jaminan mutu penyaluran listrik kepada pelanggan.

\section{DAFTAR PUSTAKA}

JAHROMI AND PIERCY, R. (2019). An Approach to Power Trabsformer Asset Management. IEEE.

ALQUDSI, A., AND EL-HAG, A. (2019). Application of Machine Learning in Transformer Health Index Prediction. Energies, 12(14),

$1-13$. https://doi.org/10.3390/en12142694

AZZOUNI, A., AND PUJOLLE, G (2017). NeuTM : A Neural Network-based Framework for Traffic Matrix Prediction in NeuTM : A Neural Network-based Framework for Traffic Matrix Prediction in SDN. October.

BABU, G. S., ZHAO, P., AND LI, X. L. (2016). Deep Convolutional Neural Network Based Regression Approach for Estimation of Remaining Useful Life. Lecture Notes in Computer Science (Including Subseries Lecture Notes in Artificial Intelligence and Lecture Notes in Bioinformatics), 9642, 214-228. https://doi.org/10.1007/978-3-319-32025-0_14

CEFERIN, S., JANC, G., TOROS, Z., KASTELIC, T., AND PRASNIKAR, B. (2017). Power Transformer Monitoring Systems for Better Asset Management. CIRED - Open Access Proceedings Journal, 2017(1), 395-399. https://doi.org/10.1049/oap-cired.2017.1262

DE, A., AND DO, N. (2018). Estimating the Remaining Lifetime of Power Transformers Using Paper Insulation Degradation.

DIWYACITTA, K., PRASOJO, R. A., SUWARNO,
S., AND GUMILANG, H. (2017). Effects of Lifetime and Loading Factor on Dissolved Gases in power transformers. ICECOS 2017 Proceeding of 2017 International Conference on Electrical Engineering and Computer Science: Sustaining the Cultural Heritage Toward the Smart Environment for Better Future, 243-247. https://doi.org/10.1109/ICECOS.2017.816714 2

DONG, M., AND GRUMBACH, L. S. (2019). Combining Unsupervised and Supervised Learning for Asset Class Failure Prediction in Power Systems. ArXiv.

GULTOM, P., DANIAL, I, AND RAJAGUKGUK, M. (2017). Studi Susut Umur Transformator Distribusi $20 \mathrm{KV}$ Akibat Pembebanan Lebih. Jurnal Teknik Elektro Universitas Tanjungpura, 2.

ISTIAKE SUNNY, M. A., MASWOOD, M.M.S, AND ALHARBI, A. G. (2020). Deep Learaning-Based Stock Price Prediction Using LSTM and Bi-Directional LSTM Model. NILES 2020, 87-92. https://doi.org/10.1109/NILES50944.2020.925 7950

KAVITHA, VARUNA AND RAMYA. (2016). A Comparative Analysis on Linear Regression and Support Vector Regression. IC-GET.

KUMAR, J., GOOMER, R., AND SINGH, A. K. (2018). Long Short Term Memory Recurrent Neural Network (LSTM-RNN) Based Workload Forecasting Model for Cloud Datacenters. Procedia Computer Science, 125, 676-682.

https://doi.org/10.1016/j.procs.2017.12.087

LEECUN, Y., BENGIO, Y., AND HINTON, G. (2015). Deep learning. Nature, 521(7553), 436-444. https://doi.org/10.1038/nature14539

MA, M., \& MAO, Z. (2019). Deep recurrent convolutional neural network for remaining useful life prediction. 2019 IEEE International Conference on Prognostics and Health Management, ICPHM 2019, 1-4. https://doi.org/10.1109/ICPHM.2019.8819440

MICELI, P. A., BLAIR, W. D., ANF BROWN, M. M. (2018). Deep Learning with Python. In 2018 21st International Conference on Information Fusion, FUSION 2018. https://doi.org/10.23919/ICIF.2018.8455530

Rizki, Y. Y., \& Ervianto, E. (2019). Perkiraan umur 
548 Jurnal Teknologi Informasi dan Ilmu Komputer (JTIIK), Vol. 8, No. 3, Juni 2021, hlm. 539-548

transformator berdasarkan pengaruh pembebanan dan temperatur lingkungan menggunakan metode trend linear. Jom Fteknik, 6(2), 1-8.

SAKINAH, N., TAHIR, M., BADRIYAH, T., AND SYARIF, I (2019). LSTM with Adam Optimization-Powered High Accuracy Preeclampsia Classification. IES 2019 International Electronics Symposium: The Role of Techno-Intelligence in Creating an Open Energy System Towards Energy Democracy, Proceedings, $\quad 314-319$. https://doi.org/10.1109/ELECSYM.2019.8901 536

SCHMIDHUBER, S. H. J. (2017). LSTM. Neural Comp, 9(8).

SONG, X., HUANG, J., AND SONG, D. (2019). Air quality prediction based on LSTM-kalman model. Proceedings of 2019 IEEE 8th Joint International Information Technology and Artificial Intelligence Conference, ITAIC 2019, Itaic, 695-699. https://doi.org/10.1109/ITAIC.2019.8785751

TJAHJONO, A., SEPTIAN, W. A., ROSMALIATI, RIKA, N. W., \& TAUFIK, T. (2019). Modeling the Temperature of the Distribution Transformer Oil Using Transformer Body Temperature and Power Quality Parameters Based on Artificial Neural Network. 2019 International Conference on Technologies and Policies in Electric Power and Energy, TPEPE 2019, https://doi.org/10.1109/IEEECONF48524.201 9.9102485

VALTER, P., LINDGREN, P., \& PRASAD, R. (2017). Artifcial Intelligence and Deep Lerning in a world of humans and persuasive busines models. IEEE. 